\title{
Chemical Modification of Polyaniline by $N$-Grafting of Polystyrenic Chains Synthesized via Nitroxide-Mediated Polymerization
}

\author{
Maryam Hatamzadeh, ${ }^{a}$ Ali Mahyar ${ }^{b}$ and Mehdi Jaymand ${ }^{* b}$ \\ ${ }^{a}$ Polymer Laboratory, Faculty of Chemistry, Payame Noor University, Tabriz, Iran \\ ${ }^{b}$ Research Center for Pharmaceutical Nanotechnology, Tabriz University of Medical Sciences, Tabriz, Iran
}

\begin{abstract}
Este estudo tem como objetivo explorar uma rota eficaz para a preparação de polianilina $N$-substituída (PANI) condutora pela incorporação de poli(estireno-co- $p$-metilestireno) de bromitano sobre a forma emeraldina de polianilina. Para este propósito, em primeiro lugar, poli(estireno-co-p-metilestireno) foi sintetizado via polimerização mediada por nitróxido (NMP), e então, $N$-bromosuccinimida foi usada como agente brominante para obter um copolímero com bromina. Em seguida, polianilina deprotonada foi reagida com poli(estireno-co-p-metilestireno) de bromitano para preparar o terpolímero poli(estireno-co-p-metilestireno)-graft-polianilina [(PSt-co-PMSt)-g-PANI] através da reação de grafitização. O terpolímero obtido foi caracterizado por espectroscopia no infravermelho por transformada de Fourier (FTIR), varredura diferencial de calorimetria (DSC) e análise termogravimétrica (TGA). Propriedades óticas do (PSt-co-PMSt)-g-PANI nos estados não-dopado e dopado foram obtidas usando espectroscopia no ultravioleta-visível (UV-Vis), e condutividade elétrica a temperatura ambiente foi medida usando amostras nas quais os materiais condutores foram ensanduichados entre dois eletrodos de Ni. Além disso, eletroatividade do terpolímero sintetizado foi verificada sob condições voltamétricas sobre a superfície do eletrodo de trabalho de carbono vítreo (GCE). A solubilidade do terpolímero (PSt-co-PMSt)-g-PANI foi examinada em solventes orgânicos comuns, tais como, tetrahidrofurano (THF), clorofórmio e xileno.
\end{abstract}

This study aims to explore an effective route for the preparation of conductive $N$-substituted polyaniline (PANI) by the incorporation of brominated poly(styrene-co- $p$-methylstyrene) onto the emeraldine form of polyaniline. For this purpose, at first, poly(styrene-co-p-methylstyrene) was synthesized via nitroxide-mediated polymerization (NMP), and then, $N$-bromosuccinimide was used as brominating agent to obtain a copolymer with bromine. Thereafter, deprotonated polyaniline was reacted with brominated poly(styrene-co-p-methylstyrene) to prepare the poly(styrene-co-p-methylstyrene)-graft-polyaniline [(PSt-co-PMSt)-g-PANI] terpolymer through $N$-grafting reaction. The terpolymer was characterized by Fourier transform infrared (FTIR) spectroscopy, differential scanning calorimetry (DSC) and thermogravimetric analysis (TGA). Optical properties of (PSt-co-PMSt)-g-PANI in the undoped and doped states were obtained by ultraviolet-visible spectroscopy (UV-Vis), and electrical conductivity at room temperature was measured using samples in which the conductive materials was sandwiched between two Ni electrodes. Moreover, electroactivity of the synthesized terpolymer was verified under cyclic voltammetric conditions on the surface of the working glassy carbon electrode (GCE). The solubility of (PSt-co-PMSt)- $g$-PANI terpolymer was examined in common organic solvents, such as, tetrahydrofuran (THF), chloroform and xylene.

Keywords: conductive polyaniline, polystyrenic chains, NMP, $N$-substitution, chemical modification

*e-mail: m_jaymand@yahoo.com, m.jaymand@gmail.com 


\section{Introduction}

Conducting polymers have attracted significant attention in recent decades because of their potential applications in various fields such as electromagnetic interference (EMI) shielding, rechargeable battery, chemical sensor, corrosion devices and microwave absorption. ${ }^{1-5}$ Among the known conducting polymers, polyaniline (PANI) has been extensively studied due to its unique electrochemical and physicochemical behaviour, good environmental stability and relatively easy preparation. ${ }^{6,7}$ However, polyaniline is inherently brittle and poor in processability due to its insolubility in common organic solvents. ${ }^{8,9}$ To improve its processability, various procedures have been adapted. For example, self-doped PANI with sulfonic acid groups substituted onto the polymer has been synthesized. ${ }^{10,11}$ Several rings and $N$-substituted PANI (soluble in common organic solvents) have been prepared directly from the polymerization of the corresponding aniline monomers. ${ }^{12-14}$ The incorporation of the side groups onto polyaniline has enhanced its solubility and processability, changing its properties. Much work has been devoted to the preparation, characterization and applications of conductive PANI/thermoplastic blends such as those based on polystyrene, polyacrylate, polyvinyl chloride, ethylene/vinyl acetate copolymers etc., most of them exhibiting good electrical conductivity even with low loading of PANI. ${ }^{15,16}$

In the past few years, it has been witnessed a rapid development in the field of controlled radical polymerization for synthesizing tailor-made polymers with well-defined architecture and predictable molecular weights. ${ }^{17-19} \mathrm{~A}$ number of techniques has been explored to achieve this control: atom transfer radical polymerization (ATRP), ${ }^{20,21}$ nitroxide-mediated polymerization (NMP) ${ }^{22,23}$ and reversible addition of fragmentation chain transfer (RAFT) ${ }^{24,25}$ Nitroxidemediated polymerization method is a controlled free radical methodology, which allows the synthesis of star and graft copolymers with controlled molecular weight under mild conditions. This polymerization method is based on the use of traditional radical initiator (e.g., benzoyl peroxide) in the presence of stable nitroxide radical (e.g., 2,2,6,6-tetramethyl-1-piperidinyloxy). Compared with other graft copolymerization such as anionic polymerization, an advantage of living free radical polymerization (LFRP) is that in the preparation of grafted copolymers, the terminal groups are stable in air at room temperature, and prepolymers can be isolated, stored and used as needed. Moreover, in anionic polymerization, stringent polymerization conditions are required. ${ }^{26-28}$
We report here our preliminary investigations on the preparation of conductive $N$-substituted polyaniline (PANI) by incorporation of brominated poly(styrene-co-pmethylstyrene) onto emeraldine form of polyaniline. For this purpose, at first, poly(styrene-co-p-methylstyrene) was synthesized via nitroxide-mediated polymerization (NMP), and then, the benzylic hydrogens of copolymer were borminated. Thus, borminated copolymer was synthesized using $\mathrm{N}$-bromosuccinimide (NBS) and 2,2'-azobis (isobutyronitrile) (AIBN) in carbon tetrachloride, as solvent. Thereafter, deprotonated polyaniline was reacted with brominated poly(styrene-co-p-methylstyrene) to prepare poly(styrene-co-p-methylstyrene)-graft-polyaniline [(PSt-co-PMSt)-g-PANI] terpolymer through $N$-grafting reaction under argon atmosphere.

\section{Experimental}

Materials

TEMPO (2,2,6,6-tetramethyl-1-piperidinyloxy) was prepared in our laboratory. ${ }^{26,27}$ Styrene, $p$-methylstyrene and aniline monomers were supplied by Merck (Darmstadt, Germany) and were distilled under reduced pressure from $\mathrm{CaH}_{2}$ before use. Tetrahydrofuran (THF) from Merck was dried by refluxing over sodium and distilled under argon prior to use. 2,2'-Azobis (isobutyronitrile) (AIBN) from Merck was recrystallized in ethanol at $50{ }^{\circ} \mathrm{C}$ before use. $N$-bromosuccinimide (NBS) from Merck was purified by recrystallization in water at $70^{\circ} \mathrm{C}$. Butyllithium (BuLi) was purchased from Merck and titrated with diphenylacetic acid before use. Ammonium persulfate (APS) from Merck was recrystallized at room temperature from ethanol/water. All other reagents were purchased from Merck and purified according to the standard methods.

\section{Synthesis of (PSt-co-PMSt) via NMP}

Styrene and $p$-methylstyrene monomers $(10 \mathrm{~mL})$ (50/50: v/v), $0.15 \mathrm{~g}(0.62 \mathrm{mmol})$ of benzyl peroxide and $0.14 \mathrm{~g}(90 \mathrm{mmol})$ of TEMPO were placed in an ampoule degassed with several freeze-pump-thaw cycles, sealed off under vacuum and placed in an oil bath at $95{ }^{\circ} \mathrm{C}$ for $4 \mathrm{~h}$. At the end of this period, the temperature was increased to $130^{\circ} \mathrm{C}$ and the mixture stirred for another $12 \mathrm{~h}$. The product was cooled, diluted with THF and precipitated into excess methanol. This product was dried overnight in vacuum at room temperature (Scheme 1). The $p$-methylstyrene content in the copolymer was $46 \%$ (by mole) based on peak at $2.28 \mathrm{ppm}\left(-\mathrm{CH}_{3}\right)$ in the ${ }^{1} \mathrm{H}$ NMR spectrum of poly(styrene-co-p-methylstyrene). 
<smiles>C=Cc1cccc([13CH2]c2cc(C=C)ccc2C)c1</smiles><smiles>Cc1ccc(C(CC(CC(ON2C(C)(C)CCCC2(C)C)c2ccccc2)c2ccccc2)C(CC(OC(=O)Cc2ccccc2)C(C)(C)C)c2ccc(C)cc2)cc1</smiles>

Scheme 1. Synthesis of (PSt-co-PMSt) via NMP.

\section{Synthesis of (PSt-co-PMSt)-Br}

A $100 \mathrm{~mL}$ three necked flask containing $30 \mathrm{~mL}$ of $\mathrm{CCl}_{4}$ and $15 \mathrm{mmol}(1.65 \mathrm{~g})$ of poly(styrene-co-pmethylstyrene) was equipped with a mechanical stirrer under argon atmosphere. In a separate container, $12 \mathrm{mmol}(2.13 \mathrm{~g})$ NBS and $10 \mathrm{mmol}(1.92 \mathrm{~g})$ of AIBN were dissolved in $30 \mathrm{~mL}$ of dried $\mathrm{CCl}_{4}$. This mixture was added at the polymer solution and stirred for $2 \mathrm{~h}$ at $70{ }^{\circ} \mathrm{C}$ under argon atmosphere, then, the mixture was cooled at room temperature and the brominated copolymer was recovered by filtration in large amount of cold methanol. This product was dried overnight in vacuum at room temperature (Scheme 2).

\section{Synthesis of polyaniline}

Polyaniline was synthesized by oxidative polymerization of aniline according to the method described in the literature..$^{29}$ Thus, $0.1 \mathrm{~mol}$ of aniline was dissolved in $123 \mathrm{~mL}$ of $p$-toluenesulfonic acid $\left(1.7 \mathrm{~mol} \mathrm{~L}^{-1}\right)$ solution. The solution was kept at $0{ }^{\circ} \mathrm{C}$ under argon atmosphere. A pre-chilled solution of $0.1 \mathrm{~mol}$ of ammonium persulfate in $134 \mathrm{~mL}$ of $p$-toluenesulfonic acid $\left(1.7 \mathrm{~mol} \mathrm{~L}^{-1}\right)$ solution was slowly added with vigorous stirring. The reaction mixture was continuously agitated for another $5 \mathrm{~h}$. The precipitate was subsequently filtered and washed several times with methanol and dried overnight in vacuum (Scheme 3).

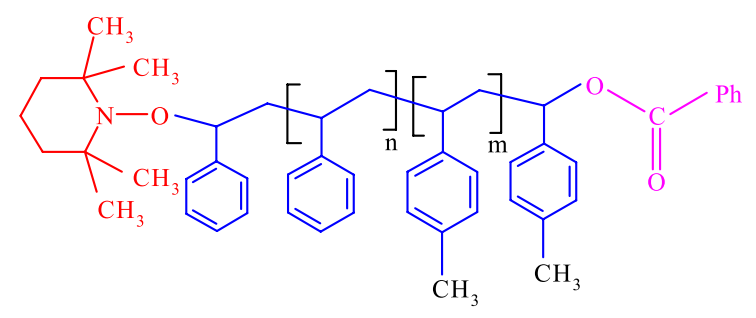

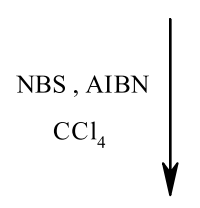

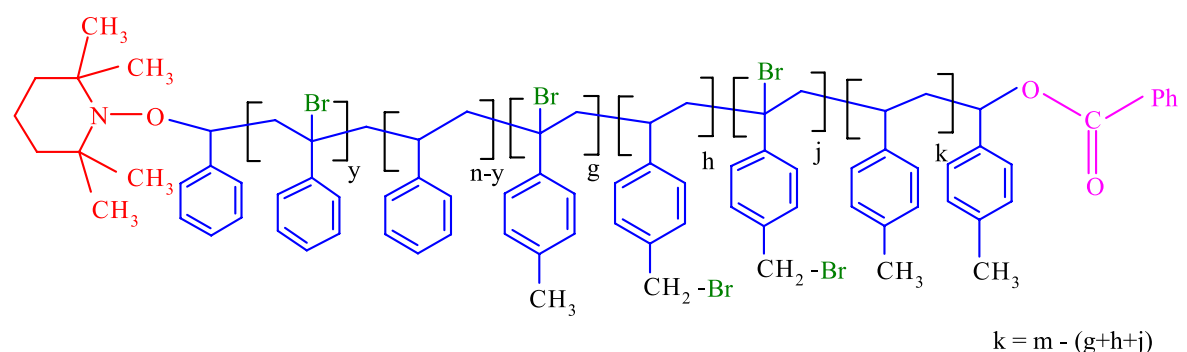

Scheme 2. Synthesis of (PSt-co-PMSt)-Br. 


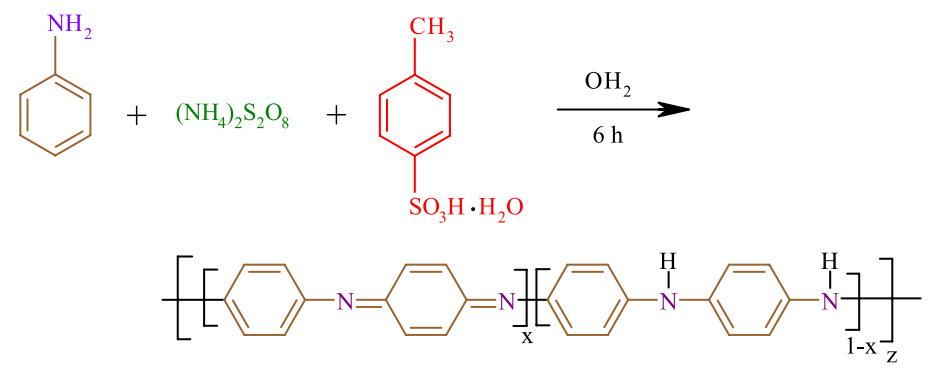

Scheme 3. Synthesis of polyaniline.

\section{Conversion of emeraldine salt to emeraldine base} polyaniline

The doped polyaniline (emeraldine salt) was later converted into its base form by stirring for $3 \mathrm{~h}$ in $3 \%$ ammonia solution. This undoped polyaniline was filtered and washed several times with excess water followed by methanol. The obtained dark blue powders were dried under vacuum at room temperature.

\section{Preparation of (PSt-co-PMSt)-g-PANI}

The reaction flask was dried and kept under an inert atmosphere throughout the reactions by a constant flow of argon. The emeraldine base form of polyaniline $(10 \mathrm{mmol}$, $1 \mathrm{~g})$ was dissolved in $50 \mathrm{~mL}$ of THF. The solution was cooled to $0{ }^{\circ} \mathrm{C}$ and the predetermined amount $(2 \mathrm{mmol})$ of BuLi was added with stirring. The colour of the solution changed from dark blue to green-black. In other dried flask, (PSt-co-PMSt)-Br (1 g) was dissolved in $20 \mathrm{~mL}$ of
THF under argon atmosphere. This solution was added to the reaction mixture. The reaction was stirred under argon atmosphere at $60{ }^{\circ} \mathrm{C}$ for $24 \mathrm{~h}$. The colour of the solution gradually turned blue. The reaction mixture was poured into excess methanol to precipitate the terpolymer. The precipitate was filtered, added to cyclohexane and refluxed to remove the residual amount of unreacted (PSt-co-PMSt)-Br (Scheme 4).

\section{Electrochemical system}

The electrochemical measurements were carried out using Auto-Lab equipment (ECO Chemie, Utrecht, The Netherlands) equipped with a three-electrode cell assembly. Glassy carbon (GC) microelectrode (with a surface area of $0.0314 \mathrm{~cm}^{2}$ ), platinum rod and $\mathrm{Ag} / \mathrm{AgCl}$ were used as working, counter and reference electrodes, respectively. The surface of the working electrode was polished with emery paper followed by 1.0 and $0.5 \mu \mathrm{m}$ alumina. To prepare glassy carbon microelectrode coated by synthesized samples, the

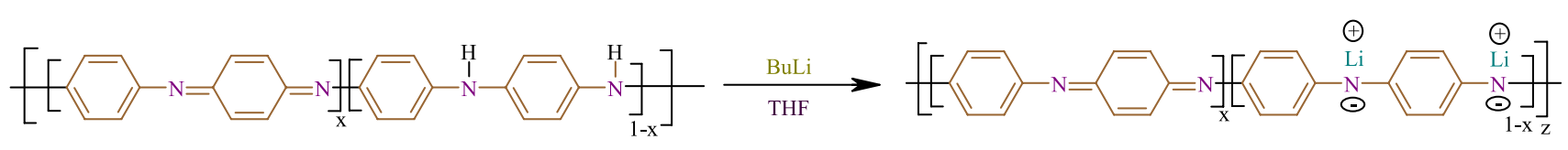

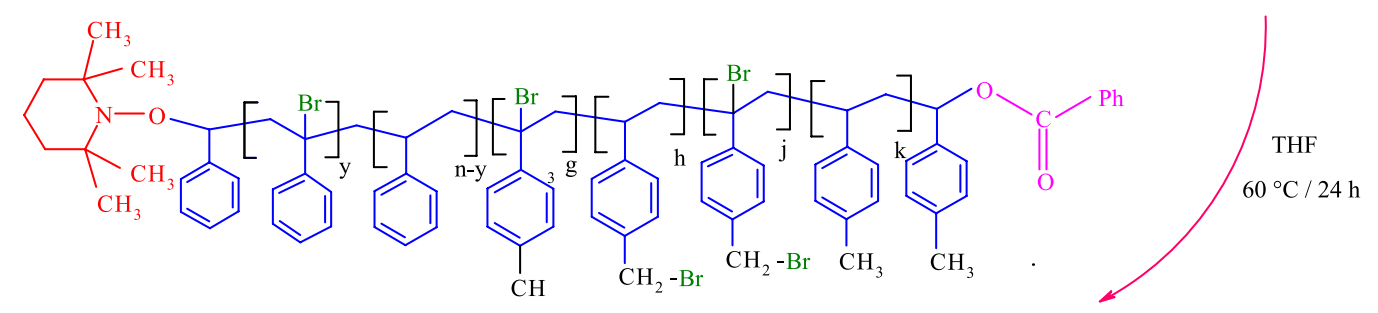

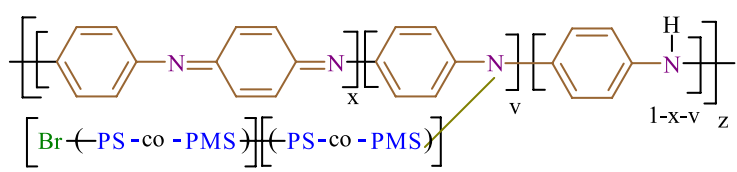

Scheme 4. Preparation of (PSt-co-PMSt)-g-PANI. 
polymers were dissolved in THF to form a $1.0 \mathrm{mg} \mathrm{mL}^{-1}$ solution and ultrasonically treated for $10 \mathrm{~min}$. The solution was dropped onto the GC microelectrode surface and allowed to dry under ambient conditions. The electrochemical measurements were accomplished in the aqueous solution of $p$-toluenesulfonic acid $\left(0.5 \mathrm{~mol} \mathrm{~L}^{-1}\right)$, by applying a sequential linear potential scan rate of $25-200 \mathrm{mV} \mathrm{s}^{-1}$ between -0.25 and $+1.0 \mathrm{~V} v s . \mathrm{Ag} / \mathrm{AgCl}$ electrode. All experimental solutions were deaerated by bubbling highly pure nitrogen for $10 \mathrm{~min}$, and a nitrogen atmosphere was kept over the solutions during the measurements.

\section{Characterization}

Fourier transform infrared (FTIR) spectra of the samples were obtained on a Shimadzu 8101M FTIR (Shimadzu, Kyoto, Japan). The samples were prepared by grinding the dry powders with $\mathrm{KBr}$ and compressing the mixture into disks. The disks were stored in a desiccator to avoid moisture absorption. The spectra were recorded at room temperature.

${ }^{1} \mathrm{H}$ nuclear magnetic resonance (NMR) spectra were obtained at $25{ }^{\circ} \mathrm{C}$ using an FT-NMR (400 MHz) Bruker spectrometer (Bruker, Ettlingen, Germany). The sample for the NMR spectroscopy was prepared by dissolving about $10 \mathrm{mg}$ of the product in $5 \mathrm{~mL}$ of deuterated chloroform or dimethyl sulfoxide.

The molecular weight of the (PSt-co-PMSt) was measured with a gel permeation chromatograph (GPC) (Maxima 820 GPC Analysis Report, Ventura, California, USA) using polystyrene $\left(10^{6}, 10^{5}\right.$ and $\left.10^{4} \AA\right)$ calibration standard with a THF mobile phase at a flow rate of $1 \mathrm{~mL} \mathrm{~min}^{-1}$ and column temperature at $25^{\circ} \mathrm{C}$.

Thermal properties of the samples were obtained with a TGA-PL STA 1640 equipment (Polymer Laboratories, Shropshire, U. K.). About $10 \mathrm{mg}$ of the sample was heated between 25 and $600{ }^{\circ} \mathrm{C}$ at a rate of $10{ }^{\circ} \mathrm{C} \mathrm{min}{ }^{-1}$ under flowing nitrogen.

Differential scanning calorimetric analyses were performed with a NETZSCH (Selb, Germany), DSC 200 F3 Maia. The sample was first heated to $200{ }^{\circ} \mathrm{C}$, and then, allowed to cool for $5 \mathrm{~min}$ to eliminate the thermal history. Thereafter, the sample was reheated to $200{ }^{\circ} \mathrm{C}$ at a rate of $10{ }^{\circ} \mathrm{C} \mathrm{min}{ }^{-1}$. The entire test was performed under nitrogen

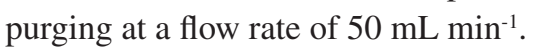

Ultraviolet-visible (UV-Vis) absorption spectra of the samples were measured using a Shimadzu 1601 PC UV-Vis spectrophotometer (Shimadzu, Kyoto, Japan) in the wavelength range of 300-1100 nm.

Electrochemical experiments were conducted using Auto-Lab PGSTA T302N. The electrochemical cell contained five openings: three of them were used for the electrodes and two for nitrogen bubbling in the solutions during all experiments. The four probe technique (Azar Electric, Tabriz, Iran) was used to measure the conductivity of $p$-toluenesulfonic acid doped (PSt-co-PMSt)- $g$-PANI and PANI samples at room temperature.

\section{Results and Discussion}

Preparation of (PSt-co-PMSt)

Living polymerization is characterized by a linear increase of the molecular weight with conversion and reaction time, and a narrow molecular weight distribution as evidenced by a dispersity index $\left(\mathrm{\Xi}=\frac{\overline{\mathrm{M}_{\mathrm{w}}}}{\overline{\mathrm{M}_{\mathrm{n}}}}\right.$, approaching $1 .^{30}$ Figure 1 represents the GPC chromatograms of the poly(styrene-co-p-methylstyrene) copolymer whose molecular weight distribution by GPC is 1.13 . The single peak of the GPC curve of the product indicated that the product could not be the blend of PSt (polystyrene) homopolymer and PMSt (poly(p-methylstyrene)) homopolymer. If so, the GPC curve should appear as two peaks, one for the PSt homopolymer and the other for the PMSt homopolymer.

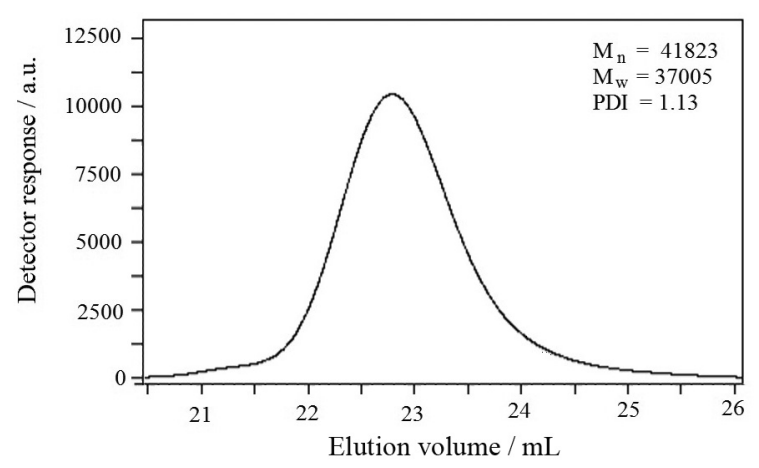

Figure 1. GPC chromatograms of the poly(styrene-co-p-metylstyrene).

\section{Preparation of (PSt-co-PMSt)-Br}

Figure 2 shows the FTIR spectra of the poly(styrene-co-pmethylstyrene) copolymer (Figure 2a) and brominated copolymer (Figure 2b). The FTIR spectrum of (PSt-co-PMSt) copolymer shows the characteristic absorption bands ${ }^{26,27}$ due to stretching vibration of $\mathrm{C}-\mathrm{H}$ $\left(3100-2850 \mathrm{~cm}^{-1}\right)$, weak aromatic overtone and combination bands in the $2100-1670 \mathrm{~cm}^{-1}$ region, $\mathrm{C}=\mathrm{C}$ stretching vibrations (1606 and $\left.1485 \mathrm{~cm}^{-1}\right), \mathrm{CH}_{2}$ bending vibrations (1445 and $\left.1372 \mathrm{~cm}^{-1}\right)$ and $\gamma(\mathrm{C}-\mathrm{H})$ in the aromatic ring (768 and $709 \mathrm{~cm}^{-1}$ ). Compared with that of (PSt-co-PMSt), a new peak at $557 \mathrm{~cm}^{-1}$ attributed to $\mathrm{C}-\mathrm{Br}$ group in the FTIR spectrum of the brominated copolymer was observed (Figure 2b). 


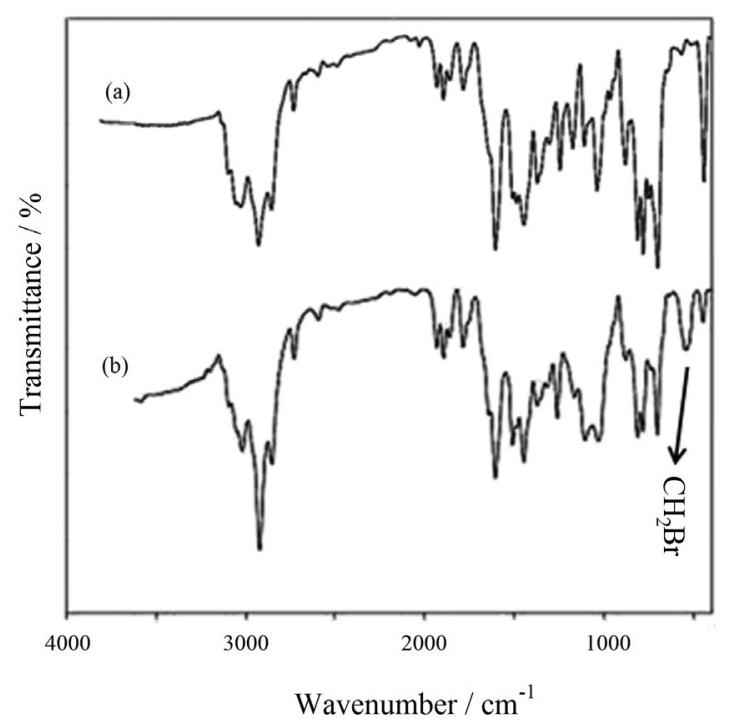

Figure 2. FTIR spectra of (a) (PSt-co-PMSt) and (b) (PSt-co-PMSt)-Br.

The ${ }^{1} \mathrm{H}$ NMR spectra of (PSt-co-PMSt) and (PSt-co-PMSt)-Br obtained by bromination of copolymer are shown in Figure 3. The ${ }^{1} \mathrm{H}$ NMR spectrum of (PSt-co-PMSt) shows the resonance at about $2.28,1.86$ and $1.43 \mathrm{ppm}$, being assigned to the $-\mathrm{CH}_{3},-\mathrm{CH}$ and $-\mathrm{CH}_{2}$ units in the copolymer, respectively, and the resonance at about 6.13-7.38 ppm are assigned to aromatic protons (Figure 3a). It was used (PSt-co-PMSt) as a starting polymer and $N$-bromosuccinimide as a brominating agent to obtain a copolymer with bromine. The bromination takes place in the aliphatic chain and not in the aromatic ring. Thus, both methyl groups and backbone methine carbons can be brominated in (PSt-co-PMSt). After bromination, the ${ }^{1} \mathrm{H}$ NMR spectrum shows the resonance at about 4.14-4.57 ppm, being assigned to the $\mathrm{CH}_{2}-\mathrm{Br}$ group in the brominated copolymer (Figure 3b).

To calculate the extent of bromination for the (PSt-co-PMSt) copolymer of a particular extent of bromination, the following method was adopted. Whereas $[(\mathrm{PSt}-\mathrm{co}-\mathrm{PMSt})]_{\mathrm{m}}-[(\mathrm{PSt}-\mathrm{co}-\mathrm{PMSt})-\mathrm{Br}]_{\mathrm{n}}$ represents the brominated poly(styrene-co-p-methylstyrene) copolymer. The mol\% bromination is given by $\mathrm{n} /(\mathrm{m}+\mathrm{n}) \times 100$. The area under the aliphatic region is given by $(9 n+5 m)$, and the area under the aromatic region is given by $(9 n+9 m)$. In Figure 3, solving the simultaneous equation with the integrated areas, it can be seen that $(9 \mathrm{n}+5 \mathrm{~m})=145.73$ and $(9 \mathrm{n}+9 \mathrm{~m})=154.1$, and therefore, $\mathrm{n}=2$ and $\mathrm{m}=15.11$. So, the extent of bromination is $2 / 17.11 \times 100=11.68 \%$.

\section{Preparation of (PSt-co-PMSt)-g-PANI}

Figure 4 shows the FTIR spectra of the pure PANI and (PSt-co-PMSt)- $g$-PANI. The FTIR spectrum of PANI shows $\mathrm{C}=\mathrm{N}$ in the quinoidal units appearing at $1585 \mathrm{~cm}^{-1}$, the benzenoid stretches at $1485 \mathrm{~cm}^{-1}$ and $\mathrm{N}-\mathrm{H}$ stretches at $3470 \mathrm{~cm}^{-1}$.
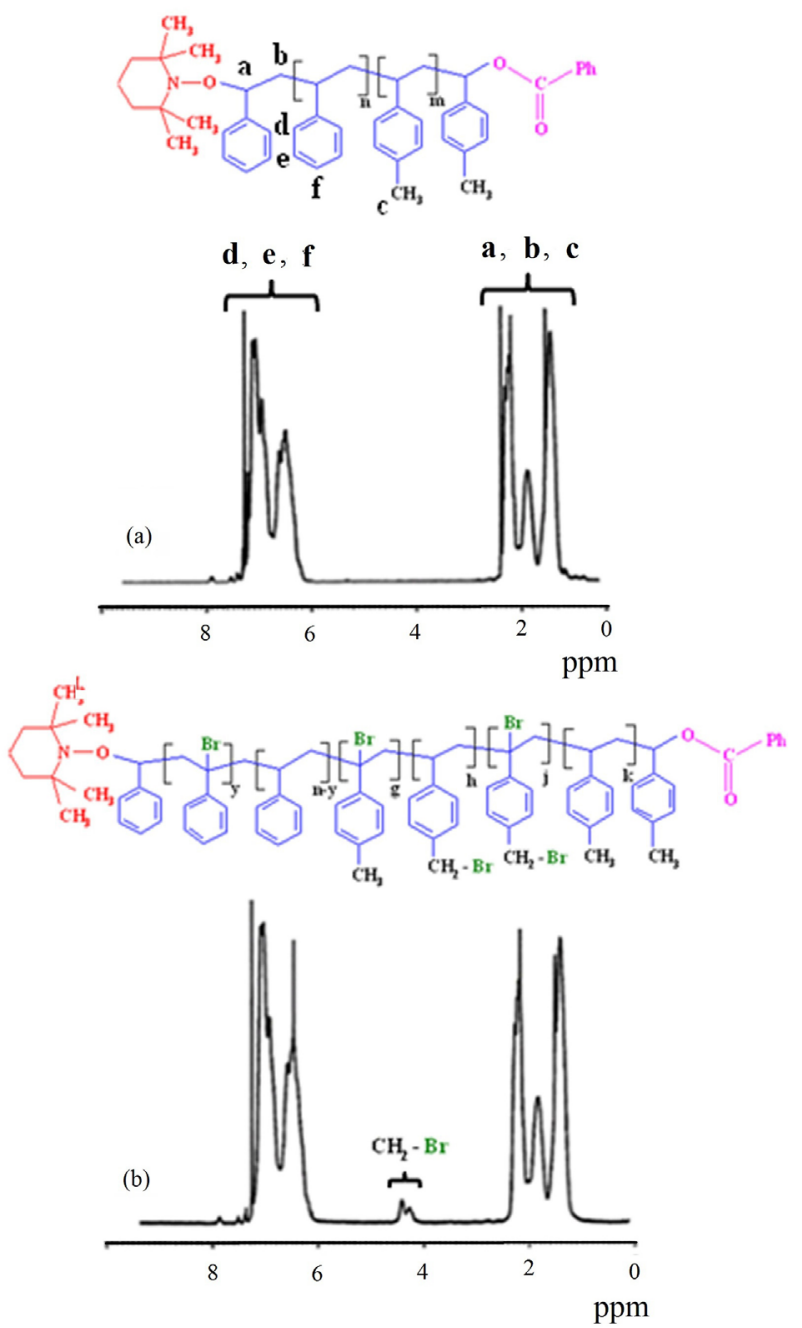

Figure 3. ${ }^{1} \mathrm{H}$ NMR spectra of (a) (PSt-co-PMSt) and (b) (PSt-co-PMSt)-Br.

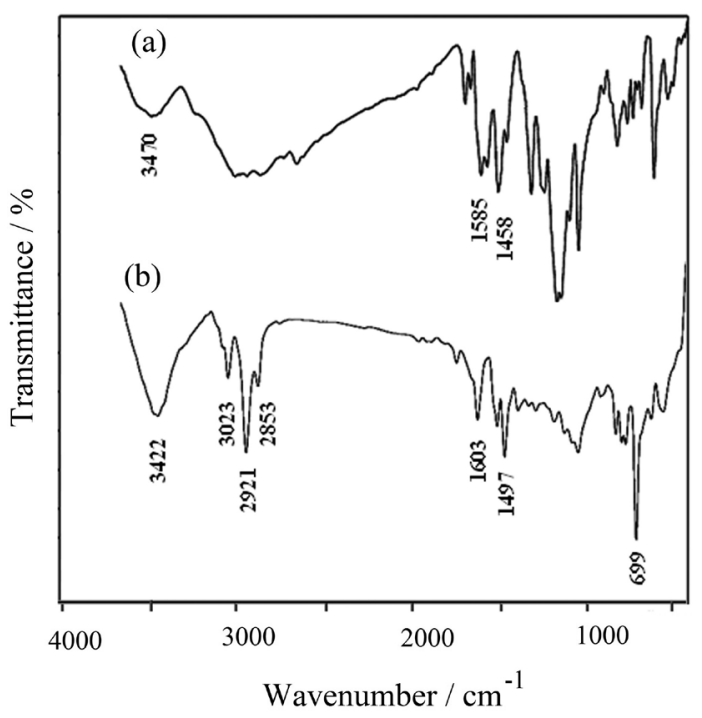

Figure 4. FTIR spectra of (a) PANI and (b) (PSt-co-PMSt)-g-PANI. 
The FTIR spectrum of (PSt-co-PMSt)-g-PANI shows characteristic absorption band of polyaniline, namely, $\mathrm{C}=\mathrm{N}$ in the quinoidal units, appearing at $1603 \mathrm{~cm}^{-1}$, the benzenoid stretches at $1497 \mathrm{~cm}^{-1}, \mathrm{~N}-\mathrm{H}$ stretches at $3422 \mathrm{~cm}^{-1}$ and the aromatic $\mathrm{C}-\mathrm{H}$ stretches at $3023 \mathrm{~cm}^{-1}$. The $\mathrm{C}_{\text {aromatic }}-\mathrm{N}$ stretching band of an aromatic amine appears at $1310 \mathrm{~cm}^{-1}$. The absorption band at $1165 \mathrm{~cm}^{-1}$ is characteristic of electron-like absorption of the $\mathrm{N}=\mathrm{Q}=\mathrm{N}$ vibration (where $\mathrm{Q}$ denotes the quinoid ring). ${ }^{31}$ The presence of the absorption band at $1270 \mathrm{~cm}^{-1}$ (attributed to the aliphatic $\mathrm{C}-\mathrm{N}$ stretching) suggests that the polystyrenic chains are linked on the nitrogens of polyaniline, while neither the position nor the intensity of the aromatic $\mathrm{C}-\mathrm{N}$ stretching band at $1311 \mathrm{~cm}^{-1}$ changes after grafting. ${ }^{32}$ The absorption band at $817 \mathrm{~cm}^{-1}$ (characteristic of the out-of-plane bending vibration of the 1,4-disubstituted benzene ring, polystyrene and poly ( $p$-methylstyrene)) has characteristic peaks at 2921 and $2853 \mathrm{~cm}^{-1}$, being attributed to aliphatic $\mathrm{C}-\mathrm{H}$ stretchings, and 759 and $699 \mathrm{~cm}^{-1}$ peaks correspond to the out-of-plane hydrogen deformation that indicates the existence of the polystyrenic chains in our sample. ${ }^{33}$

Additional evidence for the synthesis of the (PSt-co-p-PMSt)- $g$-PANI was also obtained from ${ }^{1} \mathrm{H}$ NMR data. The ${ }^{1} \mathrm{H}$ NMR spectrum of the (PSt-co-p-PMSt)- $g$-PANI is shown in Figures 5. The ${ }^{1} \mathrm{H}$ NMR spectrum of the product indicates the formation of (PSt-co-p-PMSt)- $g$-PANI terpolymer because the chemical shifts at 6.24-7.36 and 1.32-2.46 ppm represent aromatic and aliphatic protons of (PSt-co-p-PMSt)-g-PANI, respectively. The chemical shift of $-\mathrm{NH}$ proton of polyaniline in terpolymer is absent

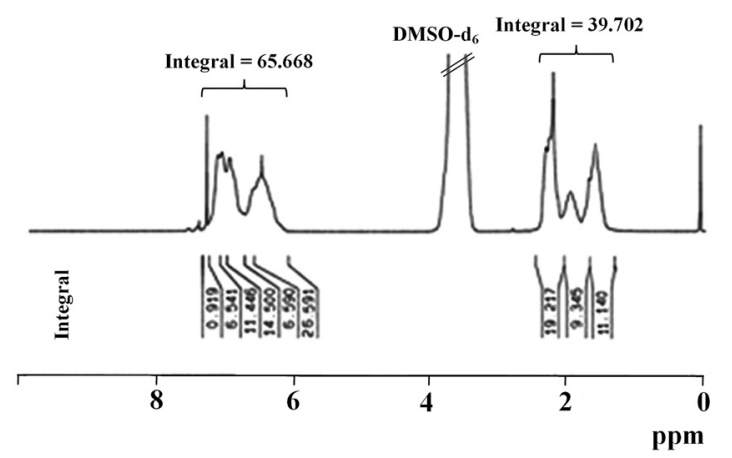

Figure 5. ${ }^{1} \mathrm{H}$ NMR (DMSO- $d_{6}, 400 \mathrm{MHz}$ ) spectrum of (PSt-co-PMSt)$g$-PANI. in the ${ }^{1} \mathrm{H}$ NMR spectrum because this peak overlaps with the peaks from DMSO- $d_{6}$.

Furthermore, before the incorporation of brominated (PSt-co-p-PMSt) onto emeraldine form of PANI, the ratio of aliphatic hydrogens to aromatic hydrogens in brominated (PSt-co-p-PMSt) is [9- $(9 \times 0.1168): 9 c a .1: 1.13]$. After incorporation of (PSt-co-p-PMSt)-Br onto emeraldine form of PANI, an increase in the ratio (39.702:65.668 ca. 1:1.66) of the integration intensity of the terpolymer aromatic hydrogens to that of the terpolymer aliphatic hydrogens can be attributed to the fact that (PSt-co-p-PMSt)-Br was incorporated into PANI, and that (PSt-co-p-PMSt)- $g$-PANI was successfully synthesized.

To calculate the extent of the presence of PANI in the synthesized terpolymer, the following method was adopted. Before incorporation of (PSt-co-p-PMSt)-Br onto PANI, the ratio of aliphatic hydrogens to aromatic hydrogens in (PSt-co-p-PMSt)-Br was [9- $(9 \times 0.1168)$ :9]. After the incorporation of (PSt-co-p-PMSt)-Br, this ratio changed to (39.702:65.668 ca. 1:1.66). Thus, $[9-(9 \times 0.1168)]:[9+4 \mathrm{X}] c a \cdot 1: 1.66$, where $\mathrm{X}$ is the percent of PANI in the terpolymer, $(9+4 \mathrm{X})$ is the number of aromatic hydrogens in the (PSt-co-p-PMSt)- $g$ PANI [ 9 for (PSt-co-p-PMSt)-Br and 4 for PANI], $[9-(9 \times 0.1168)=7.95]$ is the number of aliphatic hydrogens in the (PSt-co-p-PMSt)-Br and also in the (PSt-co-p-PMSt)- $g$-PANI. In Figure 5, by solving the equation, it can be seen that $X=13.25 \%$.

The solubility of the $\mathrm{N}$-grafted polyaniline in common organic solvents are shown in Table 1. Polystyrene and poly ( $p$-methylstyrene) have excellent solubility in non-polar solvents. The solubility of (PSt-co-PMSt)-g-PANI in common organic solvents improved compared to pure PANI because polystyrene and poly ( $p$-methylstyrene) were incorporated to the polyaniline backbone.

\section{Thermal property study}

Figure 6 shows the DSC curves of (PSt-co-PMSt) and (PSt-co-PMSt)- $g$-PANI. The neat (PSt-co-PMSt) exhibits an endothermic peak approximately at $80^{\circ} \mathrm{C}$, corresponding to the glass transition temperature $\left(\mathrm{T}_{\mathrm{g}}\right)$. Figure $6 \mathrm{~b}$ exhibits an endothermic peak approximately at $103{ }^{\circ} \mathrm{C}$, being

Table 1. Solubility of polyaniline and (PSt-co-PMSt)-g-PANI in common organic solvents

\begin{tabular}{lcccccc}
\hline Solvent & DMSO & NMP & THF & $\mathrm{CHCl}_{3}$ & Xylene & DMF \\
\hline PANI & +++ & +++ & + & + & - & ++ \\
P(St-co-MSt)- $g$-PANI & ++ & ++ & +++ & ++ & + & +++ \\
\hline
\end{tabular}

+++ : soluble; ++: sparingly soluble; + : slightly soluble; -: insoluble; the concentration used in the solubility test was $10 \mathrm{mg}$ of each polymer in $1 \mathrm{ml}$ of solvents; high molecular weight polyaniline is not soluble in $\mathrm{CHCl}_{3}$ or THF. 
attributed to the evaporation of any residual water and solvent molecules present in the terpolymer matrix. The transition observed at $228{ }^{\circ} \mathrm{C}$ can be designed as the glass transition temperature of the terpolymer. A strong exothermic peak appears at $204{ }^{\circ} \mathrm{C}$ that indicates the degradation of the dopant ( $p$-toluenesulfonic acid).

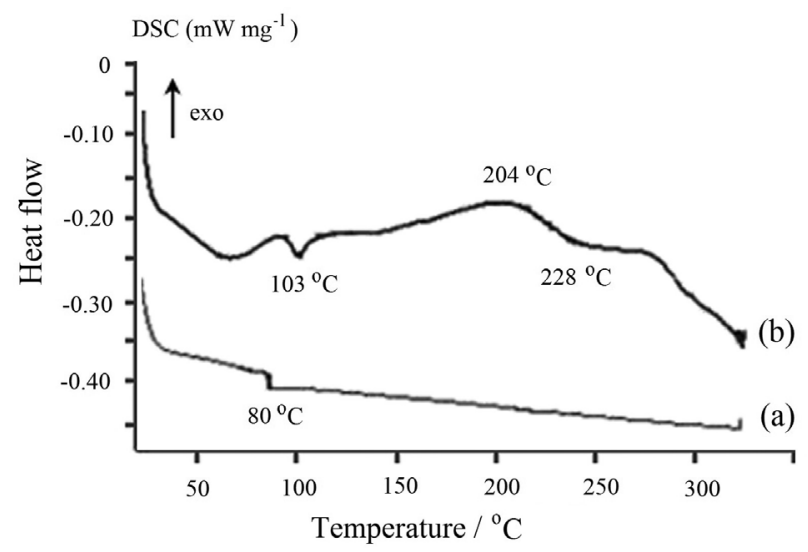

Figure 6. DCS curves of (a) (PSt-co-PMSt) and (b) (PSt-co-PMSt)-gPANI.

Characteristic TGA curves of (PSt-co-PMSt) and (PSt-co-PMSt)- $g$-PANI are shown in Figure 7. TGA results indicate improvement of the thermal stability for (PSt-co-PMSt)-g-PANI compared to neat (PSt-co-PMSt) copolymer. According to Figure 7a, it can be drawn the conclusion that the weight-loss around $400{ }^{\circ} \mathrm{C}$ in the TGA curve of (PSt-co-PMSt) is a result of the copolymer decomposition. Higher decomposition temperature of (PSt-co-PMSt)- $g$-PANI $\left(450{ }^{\circ} \mathrm{C}\right)$ compared with pure copolymer $\left(400^{\circ} \mathrm{C}\right)$ indicated that (PSt-co-PMSt)- $g$-PANI was successfully synthesized.

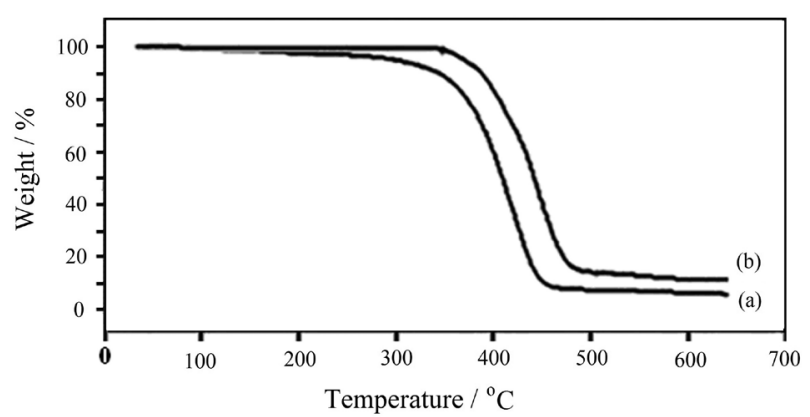

Figure 7. TGA curves of (a) (PSt-co-PMSt) and (b) (PSt-co-PMSt)-gPANI.

Electrical conductivity and electroactivity measurements of terpolymer

The most important physical properties of conductive polymers are the electrical conductivity properties. ${ }^{34}$ The electrical resistivity $(\mathrm{R})$ of the test sample was measured at room temperature and then converted to specific volume resistivity $(\rho)$ using the equation: $R=\rho L / A$. In this equation, $\mathrm{A}$ is the test sample cross section area and $\mathrm{L}$ the sample thickness. Finally, the electrical conductivity $(\sigma)$ is the reciprocal of $\rho(\sigma=1 / \rho)$. The electrical conductivity values $(\sigma)$ of PANI and (PSt-co-PMSt) $-g$ PANI terpolymer were obtained 1.29 and $0.17 \mathrm{~S} \mathrm{~cm}^{-1}$, respectively.

The effect of the potential scanning rate (V) on the peak current for the pure PANI and on the synthesized (PSt-co-PMSt)- $g$-PANI modified electrodes was studied in the range of $25-200 \mathrm{mV} \mathrm{s}^{-1}$, as shown in Figure 8. The polymer films were prepared on glassy carbon electrode (GCE) by casting. Typical cyclic voltammograms (CVs) of the pure PANI film are shown in Figure $8 \mathrm{~b}$. When $\mathrm{CV}$ s of pure PANI are recorded between -0.25 and $+1.0 \mathrm{~V} v s$. $\mathrm{Ag} / \mathrm{AgCl}$ at scan rate of $25 \mathrm{mV} \mathrm{s}^{-1}$, the oxidation and reduction peak currents were observed at approximately 0.12 and $0.29 \mathrm{~V}$ vs. $\mathrm{Ag} / \mathrm{AgCl}$, respectively, indicating that the electrochemical doping/undoping was chemically reversible. CVs of pure PANI at different scan rates showed that the anodic peak current for PANI is linearly increased with the scanning rate. The (PSt-co-PMSt) sample does not show any oxidation and reduction peaks. Figure 8a shows that the (PSt-co-PMSt) sample is a nonelectroactive polymer.

As shown in Figure 8c, cyclic voltammograms of (PSt-co-PMSt)- $g$-PANI terpolymer exhibit some qualitative similarities with those of unsubstituted polyaniline. To evaluate the electroactivity further, it was determined the relationship between the peak current size $v s$. scan rate. Figure $8 \mathrm{~d}$ shows a linear relationship between the current and scan rate between 25 and $200 \mathrm{mV} \mathrm{s}^{-1}$ in (PSt-co-PMSt)- $g$-PANI terpolymer.

\section{UV-Vis spectroscopy}

The UV-Vis spectrum of the undoped PANI dissolved in dimethyl sulfoxide (DMSO) solution has two absorption band at 332 and $634 \mathrm{~nm}$ as shown in Figure 9a. The first absorption band corresponds to the overlap of the $\pi-\pi^{*}$ transition of the benzenoid rings of PANI, while the latter one is assigned as exciton absorption of the quinoid (quinonimine) rings of PANI. ${ }^{35}$ The UV-Vis spectrum of undoped (PSt-co-PMSt)- $g$-PANI is characterized by only one electronic transition at about $598 \mathrm{~nm}$, being lower comparing with the unsubstituted PANI. This shift to shorter wavelength is ascribed of the significantly lower concentration of these quinoneimine units in the case of 

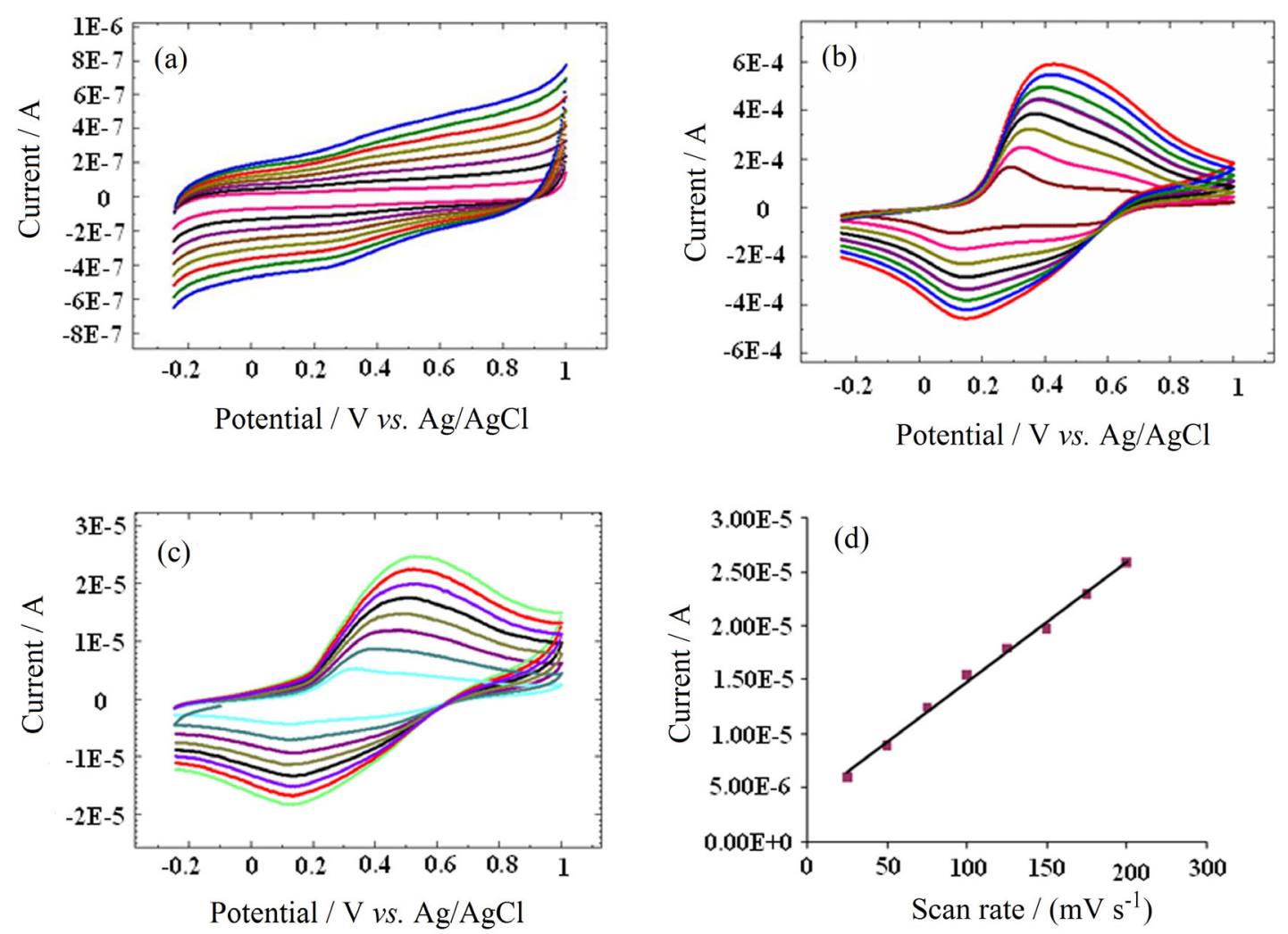

Figure 8. Cyclic voltammetry curves of (a) pure (PSt-co-PMSt), (b) neat PANI and (c) (PSt-co-PMSt)-g-PANI, and (d) linear relationship between current and scan rate in (PSt-co-PMSt)-g-PANI.

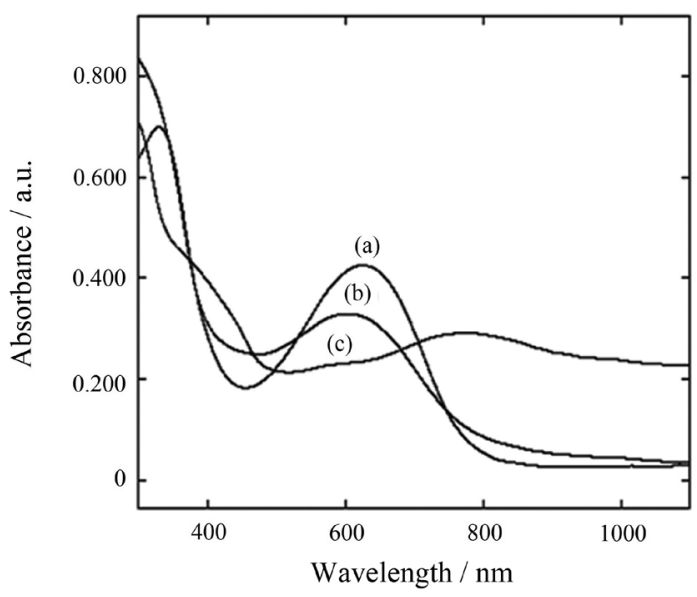

Figure 9. Electronic spectra of (a) undoped PANI, (b) undoped (PSt-co-PMSt)- $g$-PANI and (c) $\mathrm{HCl}$ doped (PSt-co-PMSt)- $g$-PANI in DMSO solution.

undoped (PSt-co-PMSt)-g-PANI in comparison with the undoped PANI.

As depicted in Figure $9 \mathrm{c}$, when the (PSt-co-PMSt)- $g$-PANI is doped by $1.0 \mathrm{~mol} \mathrm{~L}^{-1} \mathrm{HCl}$, the absorption band at about $600 \mathrm{~nm}$ completely disappeared. However, a new absorption band at $789 \mathrm{~nm}$ was observed. The position of this band, which is due to the formation of polarons (radical cations), occurs at considerable lower energy in the (PSt-co-PMSt)-g-PANI in comparison with the unsubstituted PANI, when doped with $\mathrm{HCl}$.

\section{Conclusions}

This work has shown a facile route in the synthesis of conductive $N$-substituted polyaniline (PANI) by incorporation of brominated poly(styrene-co-pmethylstyrene) onto emeraldine form of polyaniline. The (PSt-co-PMSt) copolymer was prepared by nitroxidemediated polymerization (NMP) method. Thereafter, $\mathrm{N}$-bromosuccinimide was used as a brominating agent to obtain a copolymer with bromine. Afterwards, deprotonated polyaniline, which was the substitution of the amine nitrogen of the polyaniline units, results in the formation of negatively charged nitrogen by treatment of emeraldine base with BuLi and subsequent incorporation of (PSt-co-PMSt)-Br chains onto polyaniline backbone. The (PSt-co-PMSt)- $g$-PANI terpolymer exhibited enhanced solubility in common organic solvents in comparison with the neat PANI. The doped state of (PSt-co-PMSt)- $g$-PANI shows the polaronic band, at longer wavelength (lower energy) than doped unsubstantiated PANI in the UV-Vis spectra. Investigation of thermal behaviours of the synthesized terpolymer shows the increased flexibility 
compared with neat PANI due to the substitution. Compared with pure (PSt-co-PMS), the (PSt-co-PMSt)- $g$-PANI terpolymer shows a higher decomposition temperature and higher glass transition temperature.

\section{Acknowledgments}

We express our gratitude to the Bonyade Melli Nokhbeghan Institute and Payame Noor University for supporting this project.

\section{References}

1. Prasad, G. K.; Radhakrishnan, T. P.; Kumar, D. S.; Krishna, M. G.; Sens. Actuators, B 2005, 106, 626.

2. Jiang, J.; Li, L.; Zhu, M.; React. Funct. Polym. 2008, 68, 57.

3. Mac-Diarmid, A. G.; Yang, L. S.; Huang, W. S.; Humphrey, B. D.; Synth. Met. 1987, 18, 393.

4. Hanstein, S.; Martinez-Bonastre, A.; Nestler, U.; Bartlett, P. N.; Sens. Actuators, B 2007, 125, 284.

5. Silva, P. J. E.; Temperini, M. L. A.; Torresi, S. I. C.; J. Braz. Chem. Soc. 2005, 16, 322.

6. Li, X.; Gao, Y.; Zhang, X.; Gong, J.; Sun, Y.; Zheng, X.; Qu, L.; Mater. Lett. 2008, 62, 2237.

7. Schmid, A. L.; Torresi, S. I. C.; Bassetto, A. N.; Carlos, I. A.; J. Braz. Chem. Soc. 2000, 11, 317.

8. Hosseini, S. H.; J. Appl. Polym. Sci. 2006, 101, 3920.

9. Armitt, C. D.; Armes, S. P.; Winter, J.; Urbe, F. A.; Gottesfeld, S.; Mombourquette, C.; Polymer 1993, 34, 158.

10. Huang, W. S.; B. Humphrey, D.; Mac-Diarmid, A. G.; J. Chem. Soc., Faraday Trans. 1986, 82, 2385.

11. Chen, S. A.; Hwang, G. W.; Polymer 1997, 38, 3333.

12. Cataldo, F.; Maltese, P.; Eur. Polym. J. 2002, 38, 1791.

13. Hwang, G. W.; Wu, K. Y.; Hua, M. Y.; Lee, H. T.; Chen, S. A.; Synth. Met. 1998, 92, 39.

14. Kolaei, Z. T.; Eisazadeh, H.; Polym. Plast. Technol. Eng. 2011, 50,1438
15. Sankir, N. D.; Mecham, J. B.; Goff, R. M.; Harrison, W. L.; Claus, R. O.; Smart Mater. Struct. 2006, 15, 200.

16. Tang, Q. W.; Lin, J. M.; Wu, J. H.; Zhang, C. J.; Hao, S. C.; Carbohydr. Polym. 2007, 67, 332.

17. Jaymand, M.; Macromol. Res. 2011, 19, 998.

18. Jaymand, M.; J. Polym. Res. 2011, 18, 1617.

19. Pyun, J.; Matyjaszewski, K.; Chem. Mater. 2001, 13, 3436.

20. Maliakal, A.; Katz, H.; Cotts, P. M.; Subramoney, S.; Mirau, P.; J. Am. Chem. Soc. 2005, 127, 14655.

21. Tasdelen, M. A.; Yagci, Y.; Demirel, A. L.; Biedron, T.; Kubisa, P.; Polym. Bull. 2007, 58, 653.

22. Lin, W.; Fu, Q.; Zhang, Y.; Huang, J.; Macromolecules 2008, $41,4127$.

23. Lessard, B.; Maric, M.; Macromolecules 2008, 41, 7870.

24. Tasdelen, M. A.; Durmaz, Y.Y.; Karagoz, B.; Bicak, N.; Yagci, Y.; J. Polym. Sci., Part A: Polym. Chem. 2008, 46, 3387.

25. Guo, S. Z.; Zhang, C.; Wang, W. Z.; Liu, T. X.; eXPRESS Polymer Letters 2010, 4, 17.

26. Jaymand, M.; Polym. J. 2011, 43,186.

27. Jaymand, M.; Polymer 2011, 52, 4760.

28. Nabifara, A.; Manusa, N. T. M.; Vivaldo-Limab, E.; Lonac, L. M. F.; Penlidisa, A.; Chem. Eng. Sci. 2009, 64, 304.

29. Kaplan, S.; Conwell, E. M.; Richter, A. F.; Mac-Diarmid, A. G.; Macromolecules 1989, 22, 1669.

30. Moad, G.; Rizzardo, E.; Thang, S. H.; Aust. J. Chem. 2005, 58, 379 .

31. Chen, S. A.; Lin, L. C.; Macromolecules 1995, 28, 1239.

32. Zhao, B.; Neoh, K. G.; Kang, E. T.; Tan, K. L.; Chem. Mater. 2000, 12, 1800.

33. Tarkuc, S.; Sahin, E.; Toppare, L.; Colak, D.; Cianga, I.; Yagci, Y.; Polymer 2006, 47, 2001.

34. Jaymand, M.; Des. Monomers Polym. 2011, 14, 433.

35. Huang, K.; Qiu, H.; Wan, M.; Macromolecules 2002, 35, 8653.

Submitted: February 13, 2012

Published online: April 24, 2012 